\title{
Arenavirus Therapy in Combination with Checkpoint Blockade as an Effective Way for Better Tumour Clearance
}

\author{
Hilal Bhat ${ }^{a, b}$ Murtaza Alia Thamer A. Hamdan ${ }^{a}$ \\ aInstitute of Immunology, University of Duisburg-Essen, Essen, Germany, ${ }^{b} \mathrm{Center}$ for Molecular \\ Medicine Cologne (CMMC), University Hospital Cologne, Cologne, Germany
}

\section{Key Words}

Arenavirus • Cancer • Therapy • Checkpoint inhibitors $・$ PD-1/PD-L1

\begin{abstract}
Viruses have been widely used to treat cancer for many years and they achieved tremendous success in clinical trials with outstanding results, which has led to the foundation of companies that develop recombinant viruses for a better tumor treatment. Even though there has been a great progress in the field of viral tumor immunotherapy, until now only one virus, the oncolytic virus talimogene laherparepvec (TVEC), a genetically modified herpes simplex virus type 1 (T-VEC), has been approved by the FDA for cancer treatment. Although oncolytic viruses showed progress in certain cancer types and patient populations but they have yet shown limited efficacy when it comes to solid tumors. Only recently it was demonstrated that the immune stimulatory aspect of oncolytic viruses can strongly contribute to their anti-tumoral activity. One specific example in this context are arenaviruses, which have been shown to be non-cytopathic in nature lead to the massive immune activation within the tumor resulting in strong anti-tumoral activity. This strong immune activation might be also linked to their noncytopathic features, as their immune stimulatory potential is not self-limiting as is the case for oncolytic viruses due to their fast eradication by anti-viral immune effects. Because of this strong immune activation, arenaviruses appear superior to oncolytic viruses when it comes to potent and long-lasting anti-tumor effects in a broad variety of tumor types. Currently one of the most promising therapeutics which has turned to be very much beneficial for the treatment of different cancer types is represented by antibodies targeting checkpoint inhibitors such as PD-1/PD-L-1. In this review, we will summarize anti-tumoral effects of arenaviruses, and will discuss their potential to be combined with checkpoint inhibitors for a more efficient tumor treatment, which further emphasizes that arenavirus therapy as a viroimmunotherapy can be an efficient tool for the better clearance of tumors.




\section{Cellular Physiology Cell Physiol Biochem 2021;55:726-738 \\ \begin{tabular}{ll|l} 
and Biochemistry $10.33594 / 000000472$ & Published online:24 November 2021 & 2021 The Author(s). Published by \\
Cell Physiol Biochem Press GmbH\&Co. KG
\end{tabular}}

Bhat et al:: Arenavirus Therapy and Tumour Clearance

\section{Introduction}

Arenaviruses are enveloped, pleomorphic viruses with two single-stranded RNA genome segments comprising a virus diameter of $60-300 \mathrm{~nm}$. arenaviruses are noncytopathic and propagate rapidly by virus budding without direct harming susceptible cells and tissues. Upon infection, they lead to robust immune activation which is finally directed against infected cells which might ultimately also lead to immune-mediated damage of certain tissues and disease symptoms [1]. It is known that arenaviruses can infect humans, and the disease outcome depends on the specific arenavirus family. For example, Junin virus and Lassa virus are responsible for Lassa and Argentine haemorrhagic fever, respectively. In contrary, human infections with arenaviruses such as lymphocytic choriomeningitis virus (LCMV) or Candid\#1, a Junin virus-derived vaccine applied in countries with high prevalence of this disease, is usually asymptomatic or causes nonspecific symptoms such as fever and malaise [2,3]. While the severity of symptoms and disease outcome will differ from virus to virus, the host for most arenaviruses are rodents. Once rodents are infected, they secrete the virus in urine or faeces for a long time even for their life time. The infection can spread to humans either by coming in contact with rodents or house animals or even by eating them. Viral antibodies can be found in all people infected by arenaviruses, although antibodies appear not to play a major role in virus eradication for which virus-specific CD8 $\mathrm{T}$ cells are responsible for by attacking virus antigen expressing infected cells. In the case of LCMV, infection is initiated by the attachment of viruses to host cell receptors through the virus glycoproteins. LCMV is then endocytosed, and fusion of virus and intracellular vesicle membranes take place to result in the release of the viral ribonucleocapsid into the cytoplasm.

There are different strains of LCMV described so far. LCMV "Clone 13" is a derivative of the neurotropic "Armstrong" strain, the first LCMV strain identified in the 1930s, and the viscerotropic "Docile" strain is a derivative of the viscerotropic LCMV WE strain. LCMV WE and Armstrong infection cause acute infection in mice, where the viral particles are cleared within a few days. On the other site, Docile and Clone 13 cause chronic infection and it can take up to weeks or longer for the virus to be cleared. After virus infection occurs, a strong expansion of virus antigen-specific CD8 ${ }^{+}$cytotoxic $\mathrm{T}$ lymphocytes (CTLs) takes place, upon encountering antigen-presenting cells such as dendritic cells in the lymphoid tissues, and subsequently redistribute to non-lymphoid tissues to clear the virus by destroying pathogeninfected cells. For many viral infections, $\mathrm{CD}^{+} \mathrm{T}$ cells are regarded as crucial arm of the immune response through the action of effector cytokines and cytolysis [4], in addition CD4 $\mathrm{T}$ cells provide help for CD8 $\mathrm{T}$ cells and also B cells to mount a sufficient anti-viral immune response [5]. The activation of virus-specific $\mathrm{T}$ cells is followed by their differentiation into effector T cells that play a significant role in the resolution of the infection. For example, in the context of LCMV infection, administration of mice with LCMV Docile results in a superior and directed virus-specific $\mathrm{CD}^{+} \mathrm{T}$-cell response that is readily detectable in the spleen, resulting in efficient clearance of the virus within 2 weeks after infection. However, this scenario completely changes when using a high dose of the LCMV Docile strain, which results in a protracted infection, due to the fact that higher viral load results in higher antigenic stimulation at the onset of the infection and subsequent only transient $\mathrm{CD}^{+} \mathrm{T}$ cell responses, during which antigen-specific $\mathrm{CD} 8^{+} \mathrm{T}$ cells are induced, proliferate, and initially exhibit antiviral functions, but progressively lose this ability, and as a result of this protective immunity persistent infection develops [6, 7]. Disease progression in LCMV Docile or LCMV Clone13 infection was reported to be due to such dysfunction and exhaustion of T cells.

Recently there is substantial research ongoing in the field of virus-specific $\mathrm{T}$ cell exhaustion, a state of inability of T cells to produce cytokines such as IL-2, and loss of their high proliferative and cytotoxic capacities. The production of antiviral cytokines such as TNF- $\alpha$ and IFN- $\gamma$ is diminished, which finally results in CD8 T cell excision. Because of a 
strong T cell activation which is due to a high viral load in some organs such as the liver upon early infection, hepatocytes in the liver are infected and targeted by virus-specific CD8 T cells, which may result in immunopathology in such infected organs.

Similarly, with other strains of LCMV like WE and Armstrong, upon their infection of adult mice, there is massive virus multiplication that leads to robust expansion of antigen specific $\mathrm{CD}^{+} \mathrm{T}$ cells and virus control, and this immune activation occurs 7 to 10 days after virus infection, and is essential for virus control. Along with the CTL response that is highly relevant in the control of LCMV infection, neutralising antibodies (nAbs) occurring late in the anti-viral response play a pivotal role in the long-term control of LCMV infection whether low or high doses are applied to mice [8].

\section{Virus therapy-mediated tumour clearance}

There has been a great debate for a long time now regarding the viruses and their use to treat cancer, however since some years oncolytic viruses achieved success in Phase I and II clinical trials. Furthermore, non-oncolytic viruses such as LCMV have an immense potential to interact with the immune system and to activate the innate and adaptive immune system very efficiently virus-mediated immune activation introduces new antigens into the immune system which are recognised as a foreign entity by the immune system, and these viruses carry ligands for pattern recognition receptors which have the capacity to trigger an efficient innate immune response [9]. After infection and entering into peripheral sites, arenavirus LCMV drains to the lymphatic system where it undergoes spatiotemporally restricted replication in antigen presenting cells, and thereby specifically activate innate and adaptive immune cells [10]. Based on their immune modulatory potential, viral vectors today are developed for different cancers, with oncolytic viruses combining tumor lysis with some immune modulatory effects having achieved initial promising results. Cancer cells are specifically targeted by viruses because they are able to exploit the very same cellular defects for their replication that promote tumour growth. Some oncolytic viruses have been selected or designed to take advantage of frequent tumour-specific mutations in antiviral defence programmes. In the tumour microenvironment, different signalling pathways and transcriptional programmes are activated, and accordingly some oncolytic viruses are engineered to be dependent on these pathways. Another potential approach for effective clearance of tumour cells is to restrict virus entry into especially tumor cells based on the idea that foreign and unique antigens are overexpressed on the tumour cell surface. Such oncolytic viruses should ultimately kill tumour but not healthy cells, slowly taking over the cellular translational and transcriptional machinery and finally leading to tumor cell apoptosis Although conventional anticancer drug therapy has some success, viral tumor therapy offers several more advantages. One such advantage of using viruses as an anticancer agent is that they can be modified via recombinant DNA technology that helps for the creation of designer viruses. Another interesting property of viruses is that they promote tumour specific inflammation and immune infiltration at the site of tumour growth as reported for ovarian cancer [11], which makes oncolytic and viral tumor therapy a multimodal therapy. Anti-tumor viruses have the ability to replicate in cancer cells and considering their genetic makeup and their diverse properties, such viruses are thought to be some kind of miniature biological machines that can be programmed to specifically target and finally result in the killing of the tumour cell.

Until today there are many viral species in different stages of discovery and development, and strong efforts have been made to bring them to the clinic for the treatment of different cancer types. What is also interesting about using viruses for cancer treatment is their genetic engineering for better and more effective tumour cell lysis and killing, among them herpes viruses which are most widely investigated, some of them with different tumour cell tropism, while others have been modified and engineered for other purposes. For instance, 
genetically engineered and neuro-attenuated herpes simplex viruses (HSV) expressing different cytokines are able to improve survival when used in models of murine brain tumors [12], although it is not only confined to murine brain tumours but can target others cancers as well.

Talimogene laherparepvec (T-VEC) is a genetically modified herpes simplex virus type 1 , and is the first oncolytic virus therapy approved for the cure of advanced melanoma. It has been evaluated now in phase II and phase III clinical trails where it has demonstrated a tolerable side effect and promising efficacy which further indicated a trend towards superior overall survival as compared to granulocyte-macrophage colony stimulating factor [13]. In addition, it has also been shown in case of prostate cancer using oncolytic adenovirus harbouring IL-24 leads to better antitumor effects with no or limited toxicity to the normal cell [14].

Vesicular stomatitis virus (VSV) is an oncolytic virus that has been successfully used in murine tumour models, it is a prototypic non-segmented, negative-strand RNA virus with inherent oncolytic virus qualities. It has been observed that certain cancer cells have impaired antiviral responses induced by type I interferon that makes them more sensitive to VSV or other oncolytic viruses than normal cells, although the IFN sensitivity of oncolytic viruses is still challenging their use in a broader number of tumor types. Many groups have been trying to use genetic engineering and to develop recombinant VSV. VSV-GP (VSV pseudotyped with LCMV glycoprotein) as one example has been effective in case of malignant melanoma mouse models [15]. Similarly, rhabdovirus pseudotyped VSV-GP has also been used in case of murine prostate cancer. It was shown that long term remission occurred upon intra-tumour and also intravenous treatment of subcutaneous tumour and bone metastasis [16]. These findings regarding VSV-GP in murine prostate cancer have urged the need for further investigation and rigorous experiments to expand this therapy to other tumour models, too.

Besides oncolytic viruses being used to treat different cancers, there are many attempts where people have tried to work with arenaviruses and investigate if they have antitumor properties. Especially LCMV has nowadays been a target candidate in the race for better virus-mediated anti-tumor effects. Non-cytopathic arenaviruses such as LCMV have the tendency to propagate rapidly without directly harming susceptible tissues [1]. LCMV can infect humans but reports to date suggest that they cause if at all mostly a mild disease. The majority of arenaviruses are rodent-borne, and the arenavirus family can be divided into two groups: the Lassa-lymphocytic choriomeningitis serocomplex and the Tacaribe serocomplex, whereby the majority of work has focused on Lymphocytic choriomeningitis virus (LCMV) and LASV pathogenesis. LCMV was the first arenavirus discovered during an outbreak of St. Louis encephalitis in 1933.

Main symptoms and clinical signs of an arenavirus infection can include chest pain, gastrointestinal illness, and pharyngitis. The arenavirus strains lymphocytic choriomeningitis virus (LCMV) and Candid\#1, which is a clinically applied vaccine virus to protect against Argentine haemorrhagic fever, are usually asymptomatic or cause nonspecific symptoms such as fever, body aches, dehydration and malaise. There are some prophylactic and therapeutic treatments available for arenavirus-induced symptoms, especially for those inducing haemorrhagic fever. But most of the arenavirus-induced diseases are treated by supportive care, the only other treatment was described to be potentially ribavirin. Upon LCMV infection there is a strong immune activation taking place, especially activation of CD8 T cell responses, and the strong immune effects induced by LCMV result in anti-tumour effects in a variety of murine cancer models [17-19]. Another strategy to employ arenaviruses such as LCMV in tumour therapy is their use as attenuated tumour vaccine, such as for recombinant singleCycle LCMV, with a modified virus genome not allowing budding and replication of new virus upon infection with the potential to immunize against tumour antigens [20], although it was demonstrated that replication of LCMV is key for the induction of strong immune-mediated anti-tumoral effects. Using non-oncolytic arenaviruses may also be advantageous in inducing an anti-tumoral sustained immune surveillance. arenaviruses such as LCMV will not kill the host cell by direct cytopathic effects, thus the virus has immense chances to maintain its 
tumor cell replication until the immune response is provoked within the tumour tissue, besides that it is also known that arenavirus replication is hardly limited by an anti-viral type I interferon response [21]. Another advantage in using LCMV is that it usually fails to induce rapid neutralising antibodies to limit tumoral replication early on [22]. The control of arenavirus is mostly dependent on $\mathrm{CD}^{+} \mathrm{T}$ cells, and as long as virus-specific $\mathrm{CD}^{+} \mathrm{T}$ cells do not infiltrate in the site of the tumour, arenavirus will keep replicating for several days or longer even if the tumour cells tend to respond to the virus-induced type I interferon. Thus, LCMV appears an efficient therapeutic since it stimulates an immune response by retaining enhanced replication to promote strong tumour regression. Indeed, it was shown in a recent study that LCMV is more efficacious than oncolytic viruses such as VSV-GP and rVACV [23]. Based on these and additional data generated in our lab and previously reported, LCMV appears one of the emerging viruses that has the potential for strong anti-tumoral activities as a viroimmunotherapy.

\section{Role of CD8 T cells in cancer}

CD8 T cell (cytotoxic T lymphocyte (CTL) killer cells) responses are an important arm of the immune system in the fight against viral infections. CD8 T cells destroy virus infected cells in acute and chronic viral infections. Human pathogens where the role of CTLs have been studied in detail include human immunodeficiency virus [24, 25], hepatitis B [26, 27], and heptatitis $C$ virus $[28,29]$. Murine virus infection models are one of the most valuable tools for investigating the dynamics of CTL responses against viral infections, and LCMV has played an especially important role in this aspect $[6,30,31]$. Beside the fact that an antiviral CTL response is beneficial for the host to control an infection, it can also negatively impact the host through a phenomenon called CTL-induced pathology. This occurs if the anti-viral CTL response damages tissues sufficiently to cause disease. The correlation of CTL-mediated control and CTL-induced pathology have been studied in a great detail. In addition to having a remarkable role in the control of viral infections, CD8 T cells also have a great role to play in the case of many different cancers. T cells in tumours, also known as tumour infiltrating lymphocytes (TIL), have been studied intensively over the past years. It is now well known that $\mathrm{CD}^{+} \mathrm{T}$ cells can have a tremendous antitumor effect, and this effect is dependent on two crucial factors: firstly, $\mathrm{CD}^{+} \mathrm{T}$ cell differentiation; and secondly, infiltration of $\mathrm{CD}^{+} \mathrm{T}$ cells into the tumour site, which primarily occurs by trafficking of $\mathrm{CD}^{+} \mathrm{T}$ cells into the tumour microenvironment (see Fig. 1 for a detailed summary). There are yet many reports where scientists have linked elevated levels of cytotoxic $\mathrm{CD}^{+} \mathrm{T}$ cells in the tumour microenvironment to positive anti-tumour effects, for instance in case of breast, colorectal, glioblastoma [32] and cervical cancers [33]. Therefore, elevated CD8 ${ }^{+} \mathrm{T}$ cell levels in the tumour microenvironment often appear to result in a better prognosis in different tumour types. But the tumour microenvironment, particularly for solid tumours, also impedes CD8 ${ }^{+}$ $\mathrm{T}$ cell trafficking and function by different mechanisms like chemokine secretion, abnormal tumour angiogenesis, or the activation of inhibitory checkpoint pathways. Naive CD8 ${ }^{+}$ $\mathrm{T}$ cells, once infiltrating in the tumour bed, differentiate into effector $\mathrm{CD} 8^{+} \mathrm{T}$ cells, and further differentiate and activate into cytotoxic and memory CD8 ${ }^{+} \mathrm{T}$ cells in order to perform their targeted functions at the tumour site $[34,35]$. These activated $C D 8^{+} \mathrm{T}$ cells classically secrete cytotoxic cytokines and kill the tumour cells upon their encounter with foreign tumour antigens. Once the $\mathrm{CD} 8^{+} \mathrm{T}$ cells face the antigen they differentiate into memory $\mathrm{CD}{ }^{+} \mathrm{T}$ cells, and remain in the body to perform further specialized functions and keep the tumour under control. From the literature and tremendous research in this field, it is now well established that $\mathrm{CD} 8^{+} \mathrm{T}$ cells have remarkable antitumor effects and harnessing this potential appears to have unparalleled benefits for the overall patient benefit. 


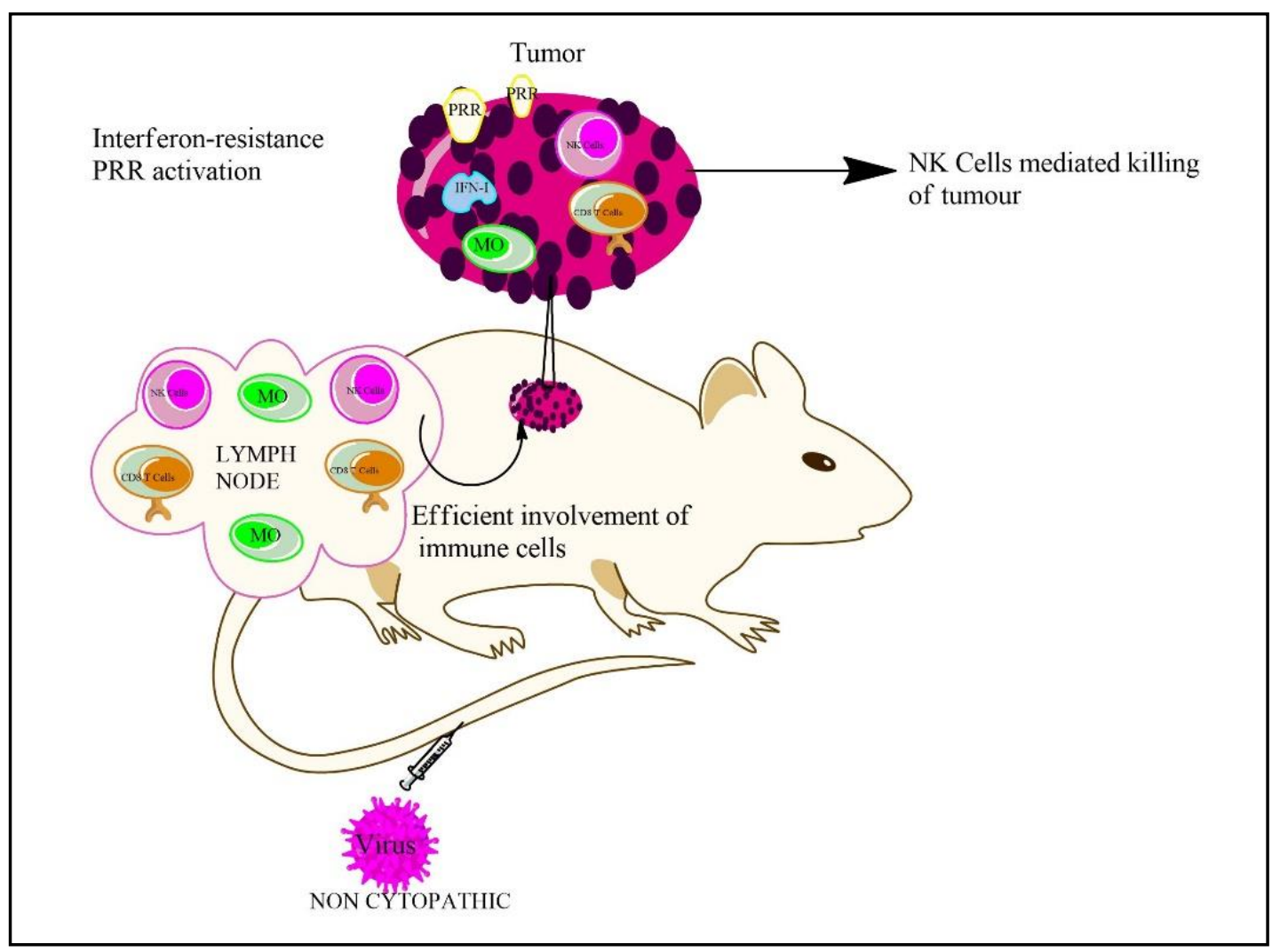

Fig. 1. Diagrammatic representation of the critical players of the lymphocytic choriomeningitis Virus (LCMV) virus-induced immune activation to result in anti-tumor activity mediated by innate (e.g., Natural killer cells (NK cells)) and adaptive (e.g., Cytotoxic CD8 T cells) immune cell types. NK (Natural Killer cells), PRR (pattern recognition receptor), IFN-1 (Type1 interferon), Mo (monocytes).

\section{Combination therapy of LCMV and checkpoint inhibitor leads to massive tumour regression}

PD-1 is expressed as a monomeric surface glycoprotein [36, 37], and is encoded by the PDCD1 gene, which contains five exons. PD-1 is expressed by a wide variety of immune cells, which are comprised by $\mathrm{CD}^{+}{ }^{+}$and $\mathrm{CD}^{+} \mathrm{T}$ cells, natural killer (NK) cells, natural killer $\mathrm{T}$ (NKT) cells, B cells, macrophages, and dendritic cell (DC) subsets. The expression of PD-1 is strongly upregulated on activated T cells, and it further can be enhanced depending on the concentration of specific stimuli. There is a significant variation in the kinetics of PD-1 expression between acute and chronic virus infection. In case of acute infection, the expression of PD-1 on antigen-specific T cells is transient, while in case of chronic infection its expression is sustained $[38,39]$. It has been investigated in [40] many chronic infections including infections with hepatitis B virus (HBV), hepatitis C virus (HCV) and human immunodeficiency virus (HIV) that antigen specific $\mathrm{T}$ cells and exhausted $\mathrm{T}$ cells express PD-1. There are many studies which have shown the impact of blockade of PD- 1 and how it will influence the course of infection. There is robust interferon-gamma and IL-2 production by HBV specific CD8 T cells once PD-1 is blocked, e.g. in the case of chronic HBV infection [41]. Similar findings have been found in relation to hepatitis $C$ virus, where a strong correlation of PD-1 expression on HCV specific CD8 T cells [42] to their functional impairment was observed, where blockade of the PD-1 pathway resulted in significant enhancement of effector functions of HCV specific CD8 T cells from peripheral blood [43]. This was in contrast to HCV specific T cells from liver, most probably due to their very high levels of 
PD-1, so that liver residing CD8 T cells appear more exhausted compared to their counter parts taken from peripheral blood [43]. PD-1 holds a great significance even in the context of HIV infection, PD-1 expression on HIV specific CD $4^{+} \mathrm{T}$ cells and $\mathrm{CD} 8^{+} \mathrm{T}$ cells is associated with T cell exhaustion which further leads to disease progression [44], and enhanced PD-1 expression was also correlated with more viral load and reduced number of $\mathrm{CD} 4^{+} \mathrm{T}$ cells [45].

In the state of chronic infection, activated T cells have enhanced PD-1 expression which further can reach to the point where these cells are non-functional, a state called $\mathrm{T}$ cell exhaustion $[38,39,46]$. Exhausted T cells lose their effector function over time with a drastic reduction of cytokine production, especially IL-2, diminished proliferative capacity and they also lose their cytotoxic capacity [47]. Mouse studies in the past especially with LCMV paved the path for a better understanding of exhausted T cells and to explain their phenotypic properties in more elucidated way. T cells which are intermediately exhausted can be rescued by blocking PD-1, however the effector function of those T cells which are terminally exhausted cannot be rescued by PD-1 blocking antibodies [48]. Some groups have demonstrated that $\mathrm{T}$ cell exhaustion can be reversed by blocking PD-1 which in turn helps them to regain their effector function and furthermore control virus replication by increasing $\mathrm{T}$ cell proliferation and enhancing effector function, killing capacity and cytokine production [38].

One of the indispensable pathways that mediate the escape of tumour cells from immune mediated destruction are the immune checkpoints $[49,50]$, and among them PD-1 is one of the most important ones, and its signalling is mediated by two of the ligands PDL1 and PD-L2 which are mainly expressed by cancer cells. There are several antibodies that have been used to target PD-1/PD-L1 and they showed beneficial effects in several tumour types including melanoma [51, 52], Hodgkin's lymphoma [53], renal cell carcinoma [54], and non-small cell lung cancer (NSCLC) [55], especially when compared to standard chemotherapy or molecular targeted therapy. In addition, it has been shown by numerous pre-clinical studies that immune checkpoint blockers have a significant effect in wide variety of cancer types. Based on this our laboratory used the murine melanoma B16 mouse model expressing the Ova antigen (B16-Ova) and investigated whether the combination of Arenavirus therapy with immune checkpoint blockade can result in more efficient anti-tumour effects. When treating tumour bearing mice with LCMV alone or in combination with antiPD1 blockade especially the combination of both LCMV and anti-PD1 blockade resulted in strongest tumour regression (Fig. 2), whereas PD1 monotherapy had as previously reported only very small anti-tumour effects in this model. These data are complemented by previous observations of our lab that blockade of PD-1 (in Pdcd $1 \%$ mice) in combination with LCMV had strongest impact on tumor growth in an advanced murine squamous oropharynx carcinoma model [23]. These important findings further emphasize that combination therapies using LCMV and checkpoint blockers are most promising as an efficient tool for increased clearance of a wide varieties of tumours.

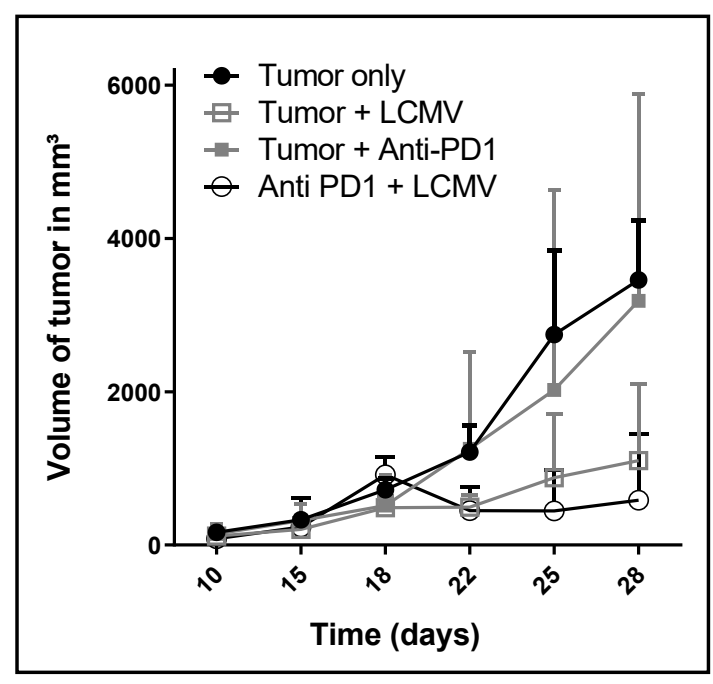

Fig. 2. The impact of LCMV combined with checkpoint therapy on melanoma tumour growth. B16Ova tumor cells $\left(2 \times 10^{6}\right.$ cells per mouse $)$ were injected subcutaneously in the left flank of $\mathrm{Bl} / 6$ mice, and once tumor reached a size of $5 \mathrm{~mm}$ on day 10 one group was treated with a LCMV strain derived from LCMV WE (i.t. application of $2 \times 10^{4}$ PFU/animal) with $(n=4)$, and another group was treated with an antibody to PD-1 alone) ( $\mathrm{n}=4)$, and a third group received the combination of LCMV and PD-1 antibody. 


\section{Cellular Physiology Cell Physiol Biochem 2021;55:726-738 \\ \begin{tabular}{ll|l} 
and Biochemistry & $\begin{array}{l}\text { DOI: 10.33594/000000472 } \\
\text { Published online: } 24 \text { November } 2021\end{array}$ & $\begin{array}{l}\text { c } 2021 \text { The Author(s). Published by } \\
\text { Cell Physiol Biochem Press GmbH\&Co. KG }\end{array}$
\end{tabular} \\ Bhat et al:: Arenavirus Therapy and Tumour Clearance}

\section{Conclusion}

From the past few decades, there has been a tremendous advancement in the field of cancer therapy. Many strategies were discovered to combat different types of cancers. For instance, genomic-guided identification of mutations that promote cancer has actually led to the development of many drugs that showed remarkable responses in tumor patients. However, such responses turned to be very much short lived and many tumours showed relapse rates. Similarly, chemotherapy shows also success, but too is limited when it comes to a complete eradication of the tumour. In contrast to the traditional chemotherapy or radiotherapy the paramount achievement in the field of cancer immunotherapy in the last decade has been undoubtedly the introduction of $\mathrm{T}$ cell targeted immunomodulators that block the immune checkpoints CTLA4, PD-1, or PDL1. This has revolutionized the field of cancer immunotherapy. Anti-PD1/PDL1 immune checkpoint inhibitors (ICIs) have become one of the most widely used anticancer therapies with significant success rates in the context of different cancer types. ICIs are now used as single agents or in combination with chemotherapy as a new strategy for more than 50 cancer types. ICIs that primarily target PD-1 have shown great promising results in melanoma and NSCLC with an overall response rate of 40-45\% [56], similarly bladder cancer patients treated with PD1/PDL-1 also showed an overall response rate of around 13-24\% [57], and similar studies were also performed with triple-negative breast cancer (TNBC), although the response of PD-1 blockade was somehow moderate around 19\% [58]. Nivolumab showed an objective response rate of $87 \%$ with a $17 \%$ complete response in relapsed or refractory Hodgkins lymphoma [59]. Indeed, ICIs have been now applicable for different cancer entities, but there still is the hope for better treatments or a cure. Only for a small fraction of patients one of the profound successes of ICIs have been a long-time remission even after the discontinuation of treatment, that raises hope for at least a small pool of patients with particular cancer types [60]. For example, in melanoma it has been examined that some patients achieved a complete response with complete disappearance of visible metastasis, observed in around $20 \%$ of patients with melanoma treated with PD-1 or with anti-CTLA4, and strikingly it is now also well accepted by the scientific community that treatment can be discontinued for such patients after 6 months of therapy as their relapse rates have been drastically reduced to around $10 \%$ over a period of a 5 year follow up [60]. Although there has been a tremendous success with the ICIs, still it is not enough for a complete cure in most patients especially from indications other than melanoma, and also many patients are refractory to ICIs where it has been shown that their cancer cells are less susceptible to T cell mediated killing via e.g., loss of Interferon -gamma response elements, or downregulation of MHC class I because of mutations in the genes that encode for JAK1 and JAK2 [61]. It is also documented that anti-PD1 or CTLA-4 also leads to the upregulation of other inhibitory receptors that result in the suppression of $T$ cell activity as has been investigated in melanoma and prostate cancer [62]. Therefore, there is a strong need for either new combination therapies or a new approach that will also include ICIs to fight tumors more efficient and including to be be used for small and larger tumours as well as their metastasis. Immunovirotherapy is a new and a promising approach that has been very efficient in cancer therapy. For instance, oncolytic viruses have been designed in a way that they can target the cancer cells directly without effecting the normal cells, oncolytic virus infection also stimulates anticancer immune cell response to a certain degree that further can accelerate efficacy of immune checkpoint inhibition. Besides viruses can change the tumour environment in a way from non-immunogenic "cold" tumours to immunogenic "hot" tumours by enhanced cytokine infiltration and also effector cell infiltration. Nevertheless, monotherapy alone even in the context of viral therapy may also have limitations, and to further address this issue one of the potential ways is to use the combination of viruses such as LCMV and ICIs, to prime the tumours and to make them more immunogenic [63]. For example, T-VEC has been used in combination with anti-PD-1 in melanoma patients where it has led to a more significant tumour regression and massive $\mathrm{T}$ cell infiltrates, enhanced IFN-gamma expression, and elevated PDL-1 protein expression, 


\section{Cellular Physiology Cell Physiol Biochem 2021;55:726-738

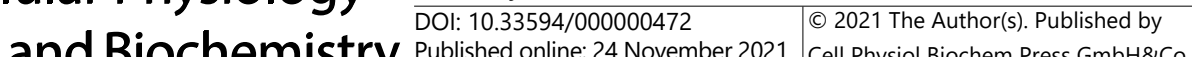 \\ Published online: 24 November 2021 Cell Physiol Biochem Press GmbH\&Co. KG \\ Bhat et al:: Arenavirus Therapy and Tumour Clearance}

which further hints towards oncolytic viral therapy possibly improving the efficacy of anti-PD-1 therapy by changing the tumour microenvironment [64]. Similar efforts have been made with oncolytic vaccinia virus where it has been shown that monotherapy of a modified oncolytic vaccinia virus in colon and ovarian mouse models does not overcome significant PD-L1 expression, but furthermore it was shown that there are synergistic effects for the combination of oncolytic vaccinia virus with anti-PD-L1 with better survival rates as compared to monotherapy [65]. To summarize combination therapies for oncolytic and immune modulating viruses appear a very efficient tool when it comes to increased tumour clearance, and viral therapy has a great potential to become the new game changer in the field of cancer biology.

\section{Acknowledgements}

We thank Dr. Jörg Vollmer from Abalos Therapeutics GmbH (Düsseldorf, Germany) who contributed helpful suggestions and comments during manuscript preparation.

\section{Funding}

This study was financially supported by Abalos Therapeutics GmbH.

\section{Disclosure Statement}

The authors declare that no conflict of interests exists.

\section{References}

1 Lang PA, Contaldo C, Georgiev P, El-Badry AM, Recher M, Kurrer M, Cervantes-Barragan L, Ludewig B, Calzascia T, Bolinger B, Merkler D, Odermatt B, Bader M, Graf R, Clavien PA, Hegazy AN, Lohning M, Harris NL, Ohashi PS, Hengartner H, et al.: Aggravation of viral hepatitis by platelet-derived serotonin. Nat Med 2008;14:756-761.

2 Enria DA, Barrera Oro JG: Junin virus vaccines. Curr Top Microbiol Immunol 2002;263:239-261.

3 Enria DA, Briggiler AM, Sanchez Z: Treatment of Argentine hemorrhagic fever. Antiviral Res 2008;78:132139.

4 Guidotti LG, Chisari FV: Noncytolytic control of viral infections by the innate and adaptive immune response. Annu Rev Immunol 2001;19:65-91.

5 Oxenius A, Zinkernagel RM, Hengartner H: CD4+ T-cell induction and effector functions: a comparison of immunity against soluble antigens and viral infections. Adv Immunol 1998;70:313-367.

6 Moskophidis D, Lechner F, Pircher H, Zinkernagel RM: Virus persistence in acutely infected immunocompetent mice by exhaustion of antiviral cytotoxic effector T cells. Nature 1993;362:758-761.

7 Moskophidis D, Kioussis D: Contribution of virus-specific CD8+ cytotoxic T cells to virus clearance or pathologic manifestations of influenza virus infection in a T cell receptor transgenic mouse model. J Exp Med 1998;188:223-232.

8 Ciurea A, Klenerman P, Hunziker L, Horvath E, Odermatt B, Ochsenbein AF, Hengartner H, Zinkernagel RM: Persistence of lymphocytic choriomeningitis virus at very low levels in immune mice. Proc Natl Acad Sci U S A 1999;96:11964-11969.

9 Honke N, Shaabani N, Zhang DE, Iliakis G, Xu HC, Haussinger D, Recher M, Lohning M, Lang PA, Lang KS: Usp18 driven enforced viral replication in dendritic cells contributes to break of immunological tolerance in autoimmune diabetes. PLoS Pathog 2013;9:e1003650.

10 Honke N, Shaabani N, Cadeddu G, Sorg UR, Zhang DE, Trilling M, Klingel K, Sauter M, Kandolf R, Gailus N, van Rooijen N, Burkart C, Baldus SE, Grusdat M, Lohning M, Hengel H, Pfeffer K, Tanaka M, Haussinger D, Recher M, et al.: Enforced viral replication activates adaptive immunity and is essential for the control of a cytopathic virus. Nat Immunol 2011;13:51-57. 


\section{Cellular Physiology Cell Physiol Biochem 2021;55:726-738 \begin{tabular}{ll|l|l|l}
\hline DOl: $10.33594 / 000000472$ & 021 The Author(s). Published by
\end{tabular} and BiOChemistry Published online: 24 November 2021 Cell Physiol Biochem Press GmbH\&Co. KG \\ Bhat et al.: Arenavirus Therapy and Tumour Clearance}

11 Benencia F, Courreges MC, Conejo-Garcia JR, Mohamed-Hadley A, Zhang L, Buckanovich RJ, Carroll R, Fraser $\mathrm{N}$, Coukos G: HSV oncolytic therapy upregulates interferon-inducible chemokines and recruits immune effector cells in ovarian cancer. Mol Ther 2005;12:789-802.

12 Russell SJ, Peng KW, Bell JC: Oncolytic virotherapy. Nat Biotechnol 2012;30:658-670.

13 Johnson DB, Puzanov I, Kelley MC: Talimogene laherparepvec (T-VEC) for the treatment of advanced melanoma. Immunotherapy 2015;7:611-619.

14 Mao LJ, Kan Y, Li BH, Ma S, Liu Y, Yang DL, Yang C: Combination Therapy of Prostate Cancer by Oncolytic Adenovirus Harboring Interleukin 24 and Ionizing Radiation. Front Oncol 2020;10:421.

15 Kimpel J, Urbiola C, Koske I, Tober R, Banki Z, Wollmann G, von Laer D: The Oncolytic Virus VSV-GP Is Effective against Malignant Melanoma. Viruses 2018;10:108.

16 Urbiola C, Santer FR, Petersson M, van der Pluijm G, Horninger W, Erlmann P, Wollmann G, Kimpel J, Culig Z, von Laer D: Oncolytic activity of the rhabdovirus VSV-GP against prostate cancer. Int J Cancer 2018;17861796.

17 Bhat H, Zaun G, Hamdan TA, Lang J, Adomati T, Schmitz R, Friedrich SK, Bergerhausen M, Cham LB, Li F, Ali M, Zhou F, Khairnar V, Duhan V, Brandenburg T, Machlah YM, Schiller M, Berry A, Xu H, Vollmer J, et al.: Arenavirus Induced CCL5 Expression Causes NK Cell-Mediated Melanoma Regression. Front Immunol 2020;11:1849.

18 O’Sullivan TE, Sun JC, Lanier LL: Natural Killer Cell Memory. Immunity 2015;43:634-645.

19 Ochsenbein AF, Sierro S, Odermatt B, Pericin M, Karrer U, Hermans J, Hemmi S, Hengartner H, Zinkernagel RM: Roles of tumour localization, second signals and cross priming in cytotoxic T-cell induction. Nature 2001;411:1058-1064.

20 Flatz L, Hegazy AN, Bergthaler A, Verschoor A, Claus C, Fernandez M, Gattinoni L, Johnson S, Kreppel F, Kochanek S, Broek M, Radbruch A, Levy F, Lambert PH, Siegrist CA, Restifo NP, Lohning M, Ochsenbein AF, Nabel GJ, et al.: Development of replication-defective lymphocytic choriomeningitis virus vectors for the induction of potent CD8+ T cell immunity. Nat Med 2010;16:339-345.

21 Lang PA, Recher M, Honke N, Scheu S, Borkens S, Gailus N, Krings C, Meryk A, Kulawik A, CervantesBarragan L, Van Rooijen N, Kalinke U, Ludewig B, Hengartner H, Harris N, Haussinger D, Ohashi PS, Zinkernagel RM, Lang KS: Tissue macrophages suppress viral replication and prevent severe immunopathology in an interferon-I-dependent manner in mice. Hepatology 2010;52:25-32.

22 Recher M, Lang KS, Navarini A, Hunziker L, Lang PA, Fink K, Freigang S, Georgiev P, Hangartner L, Zellweger R, Bergthaler A, Hegazy AN, Eschli B, Theocharides A, Jeker LT, Merkler D, Odermatt B, Hersberger M, Hengartner H, Zinkernagel RM: Extralymphatic virus sanctuaries as a consequence of potent T-cell activation. Nat Med 2007;13:1316-1323.

23 Kalkavan H, Sharma P, Kasper S, Helfrich I, Pandyra AA, Gassa A, Virchow I, Flatz L, Brandenburg T, Namineni S, Heikenwalder M, Hochst B, Knolle PA, Wollmann G, von Laer D, Drexler I, Rathbun J, Cannon PM, Scheu S, Bauer J, et al.: Spatiotemporally restricted arenavirus replication induces immune surveillance and type I interferon-dependent tumour regression. Nat Commun 2017;8:14447.

24 Leslie AJ, Pfafferott KJ, Chetty P, Draenert R, Addo MM, Feeney M, Tang Y, Holmes EC, Allen T, Prado JG, Altfeld M, Brander C, Dixon C, Ramduth D, Jeena P, Thomas SA, St John A, Roach TA, Kupfer B, Luzzi G, et al.: HIV evolution: CTL escape mutation and reversion after transmission. Nat Med 2004;10:282-289.

25 Asquith B, McLean AR: In vivo CD8+ T cell control of immunodeficiency virus infection in humans and macaques. Proc Natl Acad Sci U S A 2007;104:6365-6370.

26 Maini MK, Boni C, Lee CK, Larrubia JR, Reignat S, Ogg GS, King AS, Herberg J, Gilson R, Alisa A, Williams R, Vergani D, Naoumov NV, Ferrari C, Bertoletti A: The role of virus-specific CD8(+) cells in liver damage and viral control during persistent hepatitis B virus infection. J Exp Med 2000;191:1269-1280.

27 Guidotti LG, Rochford R, Chung J, Shapiro M, Purcell R, Chisari FV: Viral clearance without destruction of infected cells during acute HBV infection. Science 1999;284:825-829.

28 Timm J, Lauer GM, Kavanagh DG, Sheridan I, Kim AY, Lucas M, Pillay T, Ouchi K, Reyor LL, Schulze zur Wiesch J, Gandhi RT, Chung RT, Bhardwaj N, Klenerman P, Walker BD, Allen TM: CD8 epitope escape and reversion in acute HCV infection. J Exp Med 2004;200:1593-1604.

29 Sung PS, Racanelli V, Shin EC: CD8(+) T-Cell Responses in Acute Hepatitis C Virus Infection. Front Immunol $2014 ; 5: 266$. 


\section{Cellular Physiology Cell Physiol Biochem 2021;55:726-738 \begin{tabular}{l|l|l} 
DOI: $10.33594 / 000000472$ & $(c) 21$ The Author(s). Published by
\end{tabular} and BiOChemistry Published online: 24 November 2021 Cell Physiol Biochem Press GmbH\&Co. KG \\ Bhat et al:: Arenavirus Therapy and Tumour Clearance}

30 Selin LK, Lin MY, Kraemer KA, Pardoll DM, Schneck JP, Varga SM, Santolucito PA, Pinto AK, Welsh RM: Attrition of T cell memory: selective loss of LCMV epitope-specific memory CD8 T cells following infections with heterologous viruses. Immunity 1999;11:733-742.

31 Ahmed R and Oldstone MB: Organ-specific selection of viral variants during chronic infection. J Exp Med 1988;167:1719-1724.

32 Kmiecik J, Poli A, Brons NH, Waha A, Eide GE, Enger PO, Zimmer J, Chekenya M: Elevated CD3+ and CD8+ tumor-infiltrating immune cells correlate with prolonged survival in glioblastoma patients despite integrated immunosuppressive mechanisms in the tumor microenvironment and the systemic level. J Neuroimmunol 2013;264:71-83.

33 Piersma SJ, Jordanova ES, van Poelgeest MI, Kwappenberg KM, van der Hulst JM, Drijfhout JW, Melief CJ, Kenter GG, Fleuren GJ, Offringa R, van der Burg SH: High number of intraepithelial CD8+ tumor-infiltrating lymphocytes is associated with the absence of lymph node metastases in patients with large early-stage cervical cancer. Cancer Res 2007;67:354-361.

34 Harty JT, Badovinac VP: Shaping and reshaping CD8+ T-cell memory. Nat Rev Immunol 2008;8:107-119.

35 Kaech SM, Cui W: Transcriptional control of effector and memory CD8+ T cell differentiation. Nat Rev Immunol 2012;12:749-761.

36 Yokosuka T, Takamatsu M, Kobayashi-Imanishi W, Hashimoto-Tane A, Azuma M, Saito T: Programmed cell death 1 forms negative costimulatory microclusters that directly inhibit $\mathrm{T}$ cell receptor signaling by recruiting phosphatase SHP2. J Exp Med 2012;209:1201-1217.

37 Zhang X, Schwartz JC, Guo X, Bhatia S, Cao E, Lorenz M, Cammer M, Chen L, Zhang ZY, Edidin MA, Nathenson SG, Almo SC: Structural and functional analysis of the costimulatory receptor programmed death-1. Immunity 2004;20:337-347.

38 Blackburn SD, Shin H, Haining WN, Zou T, Workman CJ, Polley A, Betts MR, Freeman GJ, Vignali DA, Wherry EJ: Coregulation of CD8+ T cell exhaustion by multiple inhibitory receptors during chronic viral infection. Nat Immunol 2009;10:29-37.

39 Wherry EJ, Kurachi M: Molecular and cellular insights into T cell exhaustion. Nat Rev Immunol 2015;15:486-499.

40 Trautmann L, Janbazian L, Chomont N, Said EA, Gimmig S, Bessette B, Boulassel MR, Delwart E, Sepulveda H, Balderas RS, Routy JP, Haddad EK, Sekaly RP: Upregulation of PD-1 expression on HIV-specific CD8+ T cells leads to reversible immune dysfunction. Nat Med 2006;12:1198-1202.

41 Fisicaro P, Valdatta C, Massari M, Loggi E, Biasini E, Sacchelli L, Cavallo MC, Silini EM, Andreone P, Missale G, Ferrari C: Antiviral intrahepatic T-cell responses can be restored by blocking programmed death-1 pathway in chronic hepatitis B. Gastroenterology 2010;138:682-693, 693.e1-4.

42 Gardiner D, Lalezari J, Lawitz E, DiMicco M, Ghalib R, Reddy KR, Chang KM, Sulkowski M, Marro So, Anderson J, He B, Kansra V, McPhee F, Wind-Rotolo M, Grasela D, Selby M, Korman AJ, Lowy I: A randomized, double-blind, placebo-controlled assessment of BMS-936558, a fully human monoclonal antibody to programmed death-1 (PD-1), in patients with chronic hepatitis C virus infection. PLoS One 2013;8:e63818.

43 Nakamoto N, Kaplan DE, Coleclough J, Li Y, Valiga ME, Kaminski M, Shaked A, Olthoff K, Gostick E, Price DA, Freeman GJ, Wherry EJ, Chang KM: Functional restoration of HCV-specific CD8 T cells by PD-1 blockade is defined by PD-1 expression and compartmentalization. Gastroenterology 2008;134:1927-1937, 1937.e1-2.

44 Day CL, Kaufmann DE, Kiepiela P, Brown JA, Moodley ES, Reddy S, Mackey EW, Miller JD, Leslie AJ, DePierres C, Mncube Z, Duraiswamy J, Zhu B, Eichbaum Q, Altfeld M, Wherry EJ, Coovadia HM, Goulder PJ, Klenerman P, Ahmed R, et al.: PD-1 expression on HIV-specific T cells is associated with T-cell exhaustion and disease progression. Nature 2006;443:350-354.

45 Peligero C, Argilaguet J, Guerri-Fernandez R, Torres B, Ligero C, Colomer P, Plana M, Knobel H, Garcia F, Meyerhans A: PD-L1 Blockade Differentially Impacts Regulatory T Cells from HIV-Infected Individuals Depending on Plasma Viremia. PLoS Pathog 2015;11:e1005270.

46 Barber DL, Wherry EJ, Masopust D, Zhu B, Allison JP, Sharpe AH, Freeman GJ, Ahmed R: Restoring function in exhausted CD8 T cells during chronic viral infection. Nature 2006;439:682-687.

47 Dyck L, Mills KHG: Immune checkpoints and their inhibition in cancer and infectious diseases. Eur J Immunol 2017;47:765-779. 


\section{Cellular Physiology Cell Physiol Biochem 2021;55:726-738 \begin{tabular}{l|l|l}
\hline DOI: $10.33594 / 000000472$ & $(c) 21$ The Author(s). Published by
\end{tabular} \\ Published online: 24 November 2021 Cell Physiol Biochem Press GmbH\&Co. KG \\ Bhat et al:: Arenavirus Therapy and Tumour Clearance}

48 Paley MA, Kroy DC, Odorizzi PM, Johnnidis JB, Dolfi DV, Barnett BE, Bikoff EK, Robertson EJ, Lauer GM, Reiner SL, Wherry EJ: Progenitor and terminal subsets of CD8+ T cells cooperate to contain chronic viral infection. Science 2012;338:1220-1225.

49 Vinay DS, Ryan EP, Pawelec G, Talib WH, Stagg J, Elkord E, Lichtor T, Decker WK, Whelan RL, Kumara H, Signori E, Honoki K, Georgakilas AG, Amin A, Helferich WG, Boosani CS, Guha G, Ciriolo MR, Chen S, Mohammed SI, et al.: Immune evasion in cancer: Mechanistic basis and therapeutic strategies. Semin Cancer Biol 2015;35:S185-S198.

50 Sharma P, Allison JP: Immune checkpoint targeting in cancer therapy: toward combination strategies with curative potential. Cell 2015;161:205-214.

51 Robert C, Long GV, Brady B, Dutriaux C, Maio M, Mortier L, Hassel JC, Rutkowski P, McNeil C, KalinkaWarzocha E, Savage KJ, Hernberg MM, Lebbe C, Charles J, Mihalcioiu C, Chiarion-Sileni V, Mauch C, Cognetti F, Arance A, Schmidt H, et al.: Nivolumab in previously untreated melanoma without BRAF mutation. $\mathrm{N}$ Engl J Med 2015;372:320-330.

52 Schachter J, Ribas A, Long GV, Arance A, Grob JJ, Mortier L, Daud A, Carlino MS, McNeil C, Lotem M, Larkin J, Lorigan P, Neyns B, Blank C, Petrella TM, Hamid O, Zhou H, Ebbinghaus S, Ibrahim N, Robert C: Pembrolizumab versus ipilimumab for advanced melanoma: final overall survival results of a multicentre, randomised, open-label phase 3 study (KEYNOTE-006). Lancet 2017;390:1853-1862.

53 Nayak L, Iwamoto FM, LaCasce A, Mukundan S, Roemer MGM, Chapuy B, Armand P, Rodig SJ, Shipp MA: PD-1 blockade with nivolumab in relapsed/refractory primary central nervous system and testicular lymphoma. Blood 2017;129:3071-3073.

54 Kammerer-Jacquet SF, Deleuze A, Saout J, Mathieu R, Laguerre B, Verhoest G, Dugay F, Belaud-Rotureau MA, Bensalah K, Rioux-Leclercq N: Targeting the PD-1/PD-L1 Pathway in Renal Cell Carcinoma. Int J Mol Sci 2019;20:1692.

55 Rizvi NA, Mazieres J, Planchard D, Stinchcombe TE, Dy GK, Antonia SJ, Horn L, Lena H, Minenza E, Mennecier B, Otterson GA, Campos LT, Gandara DR, Levy BP, Nair SG, Zalcman G, Wolf J, Souquet PJ, Baldini E, Cappuzzo F, et al.: Activity and safety of nivolumab, an anti-PD-1 immune checkpoint inhibitor, for patients with advanced, refractory squamous non-small-cell lung cancer (CheckMate 063): a phase 2, single-arm trial. Lancet Oncol 2015;16:257-265.

56 Reck M, Rodriguez-Abreu D, Robinson AG, Hui R, Csoszi T, Fulop A, Gottfried M, Peled N, Tafreshi A, Cuffe S, O’Brien M, Rao S, Hotta K, Leiby MA, Lubiniecki GM, Shentu Y, Rangwala R, Brahmer JR, KEYNOTE-024 Investigators: Pembrolizumab versus Chemotherapy for PD-L1-Positive Non-Small-Cell Lung Cancer. N Engl J Med 2016;375:1823-1833.

57 Cheng W, Fu D, Xu F, Zhang Z: Unwrapping the genomic characteristics of urothelial bladder cancer and successes with immune checkpoint blockade therapy. Oncogenesis 2018;7:2.

58 Polk A, Svane IM, Andersson M, Nielsen D: Checkpoint inhibitors in breast cancer - Current status. Cancer Treat Rev 2018;63:122-134.

59 Ansell SM, Lesokhin AM, Borrello I, Halwani A, Scott EC, Gutierrez M, Schuster SJ, Millenson MM, Cattry D, Freeman GJ, Rodig SJ, Chapuy B, Ligon AH, Zhu L, Grosso JF, Kim SY, Timmerman JM, Shipp MA, Armand P: PD-1 blockade with nivolumab in relapsed or refractory Hodgkin's lymphoma. N Engl J Med 2015;372:311319.

60 Robert C, Ribas A, Hamid O, Daud A, Wolchok JD, Joshua AM, Hwu WJ, Weber JS, Gangadhar TC, Joseph RW, Dronca R, Patnaik A, Zarour H, Kefford R, Hersey P, Zhang J, Anderson J, Diede SJ, Ebbinghaus S, Hodi FS: Durable Complete Response After Discontinuation of Pembrolizumab in Patients With Metastatic Melanoma. J Clin Oncol 2018;36:1668-1674.

61 Zaretsky JM, Garcia-Diaz A, Shin DS, Escuin-Ordinas H, Hugo W, Hu-Lieskovan S, Torrejon DY, AbrilRodriguez G, Sandoval S, Barthly L, Saco J, Homet Moreno B, Mezzadra R, Chmielowski B, Ruchalski K, Shintaku IP, Sanchez PJ, Puig-Saus C, Cherry G, Seja E, et al.: Mutations Associated with Acquired Resistance to PD-1 Blockade in Melanoma. N Engl J Med 2016;375:819-829.

62 Gao J, Ward JF, Pettaway CA, Shi LZ, Subudhi SK, Vence LM, Zhao H, Chen J, Chen H, Efstathiou E, Troncoso P, Allison JP, Logothetis CJ, Wistuba, II, Sepulveda MA, Sun J, Wargo J, Blando J, Sharma P: VISTA is an inhibitory immune checkpoint that is increased after ipilimumab therapy in patients with prostate cancer. Nat Med 2017;23:551-555. 
Cellular Physiology Cell Physiol Biochem 2021;55:726-738

\begin{tabular}{ll|l} 
and Biochemistry & $\begin{array}{l}\text { DOl: } 10.33594 / 000000472 \\
\text { Published online: } 24 \text { November } 2021\end{array}$ & $\begin{array}{l}\text { C } 2021 \text { The Author(s). Published by } \\
\text { Cell Physiol Biochem Press GmbH\&Co. KG }\end{array}$ \\
\hline
\end{tabular}

Bhat et al.: Arenavirus Therapy and Tumour Clearance

63 Zamarin D, Holmgaard RB, Subudhi SK, Park JS, Mansour M, Palese P, Merghoub T, Wolchok JD Allison JP: Localized oncolytic virotherapy overcomes systemic tumor resistance to immune checkpoint blockade immunotherapy. Sci Transl Med 2014;6:226ra32.

64 Ribas A, Dummer R, Puzanov I, VanderWalde A, Andtbacka RHI, Michielin O, Olszanski AJ, Malvehy J, Cebon J, Fernandez E, Kirkwood JM, Gajewski TF, Chen L, Gorski KS, Anderson AA, Diede SJ, Lassman ME, Gansert J, Hodi FS, Long GV: Oncolytic Virotherapy Promotes Intratumoral T Cell Infiltration and Improves Anti-PD-1 Immunotherapy. Cell 2018;174:1031-1032.

65 Liu Z, Ravindranathan R, Kalinski P, Guo ZS, Bartlett DL: Rational combination of oncolytic vaccinia virus and PD-L1 blockade works synergistically to enhance therapeutic efficacy. Nat Commun 2017;8:14754. 